\title{
EXPERIMENTS WITH EVERYDAY SUBSTANCES FOR AN INTERESTING AND PRODUCTIVE LEARNING IN CHEMISTRY
}

\author{
Dagnija Cedere, Jazeps Logins, Jelena Volkinsteine \\ University of Latvia, Latvia
}

\author{
Alfred Flint \\ University of Rostock, Germany
}

\begin{abstract}
A concept "Chemistry for life" developed in Germany characterises a number of theses generally recognised in modern didactics, from which the principle "from the simple to more difficult" and psychological laws of learning are highlighted. This concept is in particular characterised by the thesis that chemistry studies should be based on student everyday notions. The foundation of chemistry studies is experimentation with everyday substances.

The concept "Chemistry for life" can be successfully used for acquiring chemistry in schools in Latvia by intensifying the use of experiments with everyday substances and developing student inquiry skills.
\end{abstract}

Key words: chemistry for life, chemistry learning process, everyday substances, experiments, inquiry skills.

\section{Introduction}

Development of science and technology, the ever increasing influence of the scientific achievements on our everyday lives create a necessity for the public to become more scientifically literate (Lamanauskas, Augienè, 2011). In order to know how to use scientific achievements in the everyday life, as well as to be able to participate in the continuation of the scientific progress, one must understand the nature of science, acquire the skill to apply the knowledge, solve problems, by making a variety of decisions both in everyday life and work settings (Russell, Weaver, 2011; Čižkova, Čtrnactova, 2011).

The education is realized when a student learns to recognise various matters, asks questions, tries to solve problems, wonders. From the point of view of the public (as well as the student) chemistry and our living environment (the environment we live in) are in constant interaction (Collin, Flint, 2009). However, upon commencing the chemistry studies in school, students doesn't always perceive the goal for which the knowledge in chemistry is necessary. Frequently students do not realize that the knowledge gained in chemistry lessons is useful in their everyday lives and future professions (Samete, Cedere, 2009). Many studies show that during the past decade student interest in science has decreased, student unwillingness to acquire the subject of chemistry is a problem characteristic of $21^{\text {st }}$ century not only in Latvia, but in many other European countries (Samete, Cedere, 2009; Flint, 2011; Гедровицс, Цедере, Еронен и др., 2012).

The guideline of the modern methodology of science education can be characterised with a following thesis: "Learning is a process of knowledge construction, individually and socially" (Zhou, 2010). In correspondence with this thesis, a concept "Chemistry 
for Life" has been developed in the University of Rostock (Germany) under the leadership of professor A. Flint, and this concept is currently being adapted in chemistry education in the schools in Latvia. The German methodology is mainly oriented towards development of student interest and understanding upon the commencement of chemistry studies.

\section{Concept "Chemistry for Life"}

A number of methodological elaborations founded on the principle of interaction between two areas of chemistry - learning chemistry and everyday chemistry - have been established under the leadership of professor A. Flint in the Department of Didactics of Chemistry of the University of Rostock (Rossov, Flint, 2007; Collin, Flint, 2008; Freienberg, Flint, 2012). A. Flint stresses that chemistry and the living environment are interconnected and continuously interact with each other. In order to improves the success of learning chemistry it is important to connect chemistry and the living environment also in the learning process, it is especially important to take this principle into consideration upon the commencement of chemistry education (according to the German education system, in grades 7 to 10) (Collin, Flint, 2009).

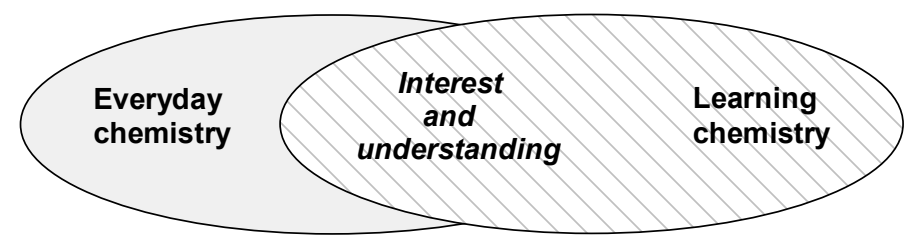

Figure 1: Principal scheme of the concept "Chemistry for Life".

The other important characteristic of the concept „Chemistry for Life” is a chemistry experiment as a source of reference and the guideline of the main cognitive process.

The concept "Chemistry for Life" is characterized by the following main theses:

- Chemistry lessons should ensure the contribution to general education comprehensible by the students themselves

The students should realize that knowledge gained during chemistry lessons is useful in their personal and daily lives, moreover not only after successful completion of the basic and extended courses in chemistry, but also at the beginning stage of chemistry education.

- As often as possible, chemistry lessons should provide a link to the everyday life

The request arises already from the necessity for the students to recognise the contribution of chemistry to their general education. Furthermore, operating with substances used in daily life provides a high potential for motivation which should be used within the limitations of the possible. However, often we are faced with two issues: substances used in everyday life are usually concerned with organic chemistry (food products, clothing, synthetic materials, etc.) and besides their composition and type of influence is often too complicated for them to be fully used during the chemistry lessons at the beginning stage of the education. Nevertheless, in order to fulfil these requirements, other approaches should be used. 
- The lessons should include current topics and curriculum

This thesis is closely connected to both previous ones. They should only be supplemented with the time factor. The study plan should foresee the time for current topics in order to leave no room for worries that the mandatory programme of the study year might not be managed.

- The basic knowledge (curriculum that cannot be discarded) is repeated and strengthened by linking separate topics

In regard to everyday life, the student interests or current events must not be on the curriculum selection criteria or structuring features of the chemistry lessons. In chemistry as in any other science subject, by acquiring the curriculum in a more extended manner, one must always return to basic knowledge. This basic knowledge should be gained and learnt to apply at the begging stage of chemistry education regardless of other defined conditions. Without it, it is impossible to neither reach an appropriate understanding nor successfully continue the chemistry education in secondary school.

- Students themselves should be actively engaged as often as possible

A good chemistry lesson is one where students are actively engaged in the learning process. This refers to mental activities during the inquisitive developmental lesson, project or other extra-curriculum event. The necessity to facilitate experimentation carried out by students should be especially highlighted. Individually performed experiments contribute to not only better remembrance and comprehension of the curriculum, but also student motivation and desire to gain success. Frequent issues concerned with safety and materials necessary for the experiments can be significantly decreased if substances found at home or purchased in supermarkets are used in these experiments as often as possible. Their usage is more favourable than the use of substances from the chemicals shelf, besides they are usually significantly less dangerous.

- $\quad$ Student mental capability and preliminary knowledge should be taken into consideration

The request is especially topical at the beginning stage of chemistry acquisition. Learning about the matters not visible to the naked eye, for instance, atoms, molecules, ions or bonds, students must have a mental notion of the concepts and must know how to handle these notions on a mental level (in accordance with the views of Jean Piaget on abstract thinking). A number of empirical studies show that often even in grade 10 of gymnasium less than $50 \%$ of students possess such mental skills.

Student actual mental capability should also be taken into consideration. It is necessary to be applied in many different aspects, for instance, establishing the problem, understanding the course of the experiment, observing, drawing conclusions, as well as abstract thinking. It should be considered that, for instance, during intense abstract thinking students are engaged in other activities, also requiring attention and thus intellectual strength as well, as little as possible. It should be taken care of that when abstract thinking is more important, students are familiar with as many topics as possible. Then the student will be able to direct the greater part of their intellectual strength towards abstract thinking.

\section{Adapting the concept "Chemistry for Life"}

The methodical material making intensified use of experiments with everyday substances, has aroused interest to study the opportunities of its application in the schools in Latvia in accordance with the needs and actual possibilities of our schools. 
Many principles brought forward by the concept "Chemistry for Life" that correspond to the beginning stage of learning chemistry (in Germany, Sekundarstufe I) are also applicable in secondary school (in Germany, correspondingly Sekundarstufe II). Here it is also important to maintain a close connection between the learning process and everyday life, thus promoting student learning activity, constructing and strengthening student knowledge and skills that will be useful to them in a number of further study areas (medicine, pharmacology, biology, chemistry) and professions (laboratory assistants, medical technicians) concerned with chemistry. As indicated by the experience of the German colleagues, by using in a classroom substances and materials corresponding to the student sphere of interests, besides the pronounced increase of learning motivation, the value of education as such also rises. Therefore, many experiments intended for the beginning stage of chemistry education are applicable also in grades 10 and 11.

The more interesting and appropriate for our chemistry education programmes are the methodical aids with captivating titles:

- "Candles, oxidising cleaning agents and camp gas correspond to the topic "Oxidation and reduction reactions"

- Lemon juice and drain cleaning agent correspond to the topic "Acids and bases"

The methodology defined in both of these methodical aids is based on simple experiments using common everyday substances and materials well-known to students. The interested teachers have done pre-approbation that demonstrates the possibility for successful application of this concept in our schools both on elementary school level, when students are beginning to familiarize with chemistry (Samete, Cedere 2010), and secondary school level, for instance, when studying the topic "Acids and Bases" (Лесиня, Цедере, 2011). As shown by the carried out studies, the cognitive process based on direct observation by the student in a self-performed experiment with well-known substances facilitates their understanding of chemical processes.

Table 1. Adapting the methodical material "Candles, oxidising cleaning agents and camp gas" for learning chemistry in elementary school (according to Rossov, Flint, 2007).

\begin{tabular}{|c|c|c|c|}
\hline No & Topic & Experiment & Substantiation \\
\hline \multirow[t]{4}{*}{1.} & \multirow{4}{*}{ 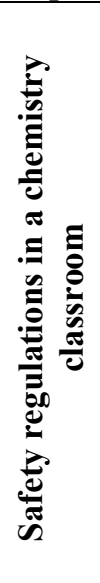 } & $\begin{array}{l}\text { Explosion of the } \\
\text { blend of petrol va- } \\
\text { pour and air }\end{array}$ & $\begin{array}{l}\text { Vividly demonstrates that the vapour of highly vola- } \\
\text { tile and inflammable substances together with air } \\
\text { create a dangerous blend. }\end{array}$ \\
\hline & & $\begin{array}{l}\text { Extinguishing burn- } \\
\text { ing spirit }\end{array}$ & Students see, how the burning can be stopped. \\
\hline & & $\begin{array}{l}\text { Extinguishing fire } \\
\text { with water }\end{array}$ & $\begin{array}{l}\text { It is established what is the importance of the tem- } \\
\text { perature at the moment of ignition in extinguishing } \\
\text { the fire and that water is a good fire extinguishing } \\
\text { agent. }\end{array}$ \\
\hline & & $\begin{array}{l}\text { Extinguishing burn- } \\
\text { ing petrol }\end{array}$ & $\begin{array}{l}\text { Students learn what consequences a choice of an } \\
\text { inappropriate extinguishing agent can have; students } \\
\text { can conclude that also the oil that has started burning } \\
\text { on a frying pan must not be put out using water. }\end{array}$ \\
\hline
\end{tabular}




\begin{tabular}{|c|c|c|c|}
\hline \multirow[t]{7}{*}{2.} & \multirow{7}{*}{ 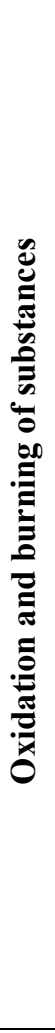 } & Ignition of paraffin & $\begin{array}{l}\text { The basic concepts such as state of aggregation, } \\
\text { melting, boiling temperature are repeated; new notion } \\
\text { - only the vapour of paraffin is inflammable. }\end{array}$ \\
\hline & & $\begin{array}{l}\text { Proving the end- } \\
\text { products of candle } \\
\text { burning }\end{array}$ & $\begin{array}{l}\text { An example for repeating and extending the knowl- } \\
\text { edge on features of chemical reactions; the experi- } \\
\text { ment verifies that by burning a candle, carbon diox- } \\
\text { ide and water is produced. }\end{array}$ \\
\hline & & $\begin{array}{l}\text { Burning of the can- } \\
\text { dles in containers of } \\
\text { various sizes }\end{array}$ & $\begin{array}{l}\text { Students come to a realization that the duration of the } \\
\text { burning of a candle is influenced by not only the } \\
\text { mass of the burning substance, but also the amount of } \\
\text { air. }\end{array}$ \\
\hline & & $\begin{array}{l}\text { Reaction of various } \\
\text { metals with the oxy- } \\
\text { gen in the air }\end{array}$ & $\begin{array}{l}\text { Student see that various metals react differently with } \\
\text { the oxygen in the air, for instance, magnesium burns } \\
\text { rapidly producing warmth and light, however the iron } \\
\text { rusts. }\end{array}$ \\
\hline & & $\begin{array}{l}\text { Burning of the iron } \\
\text { powder }\end{array}$ & $\begin{array}{l}\text { Students understand the dependence of the speed of } \\
\text { reaction on the crushing of a substance. }\end{array}$ \\
\hline & & $\begin{array}{l}\text { Burning of a "copper } \\
\text { letter" over the } \\
\text { flame of the burner }\end{array}$ & $\begin{array}{l}\text { Students see that in places where the copper comes } \\
\text { into contact with the oxygen in the air, the reaction } \\
\text { takes place. }\end{array}$ \\
\hline & & Burning of hydrogen & $\begin{array}{l}\text { Students can observe the product of combustion of } \\
\text { hydrogen and oxygen. }\end{array}$ \\
\hline \multirow[t]{2}{*}{3.} & \multirow{2}{*}{ 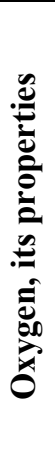 } & $\begin{array}{l}\text { Obtaining oxygen } \\
\text { from a dry oxidising } \\
\text { cleaning agent }\end{array}$ & $\begin{array}{l}\text { Students learn that when the cleaning agent is heated, } \\
\text { the oxygen is released. This knowledge gives the } \\
\text { opportunity to use oxidising cleaning agent in ex- } \\
\text { periments for producing oxygen. Thus the potassium } \\
\text { permanganate or hydrogen peroxide used until now } \\
\text { can be replaced with a substance commonly used in } \\
\text { everyday life. }\end{array}$ \\
\hline & & $\begin{array}{l}\text { Burning of charcoal } \\
\text { in oxygen }\end{array}$ & $\begin{array}{l}\text { This experiment shows that oxygen facilitates the } \\
\text { burning process better than air; students learn that the } \\
\text { precondition for complete burning is not only the } \\
\text { presence of oxygen, but also the amount of oxygen. }\end{array}$ \\
\hline
\end{tabular}

Using the concept "Chemistry for Life" for the improvement of student inquiry skills. Experiments developed by German colleagues can be successfully used in schools in Latvia in order to both bring a specific chemistry curriculum closer to everyday life and improve the student scientific inquiry skills. Following are a few examples for the improvement of student scientific inquiry skills. In these examples the experiments have been used as teacher demonstrations or as student scientific inquiry experiments. 
Table 2. Using demonstration to establish the problem of research and propose a hypothesis.

\begin{tabular}{|c|c|}
\hline Topic of the lesson & Factors influencing the speed of a chemical reaction \\
\hline $\begin{array}{l}\text { Demonstration by a } \\
\text { teacher } \\
\text { (According to Rossov, } \\
\text { Flint, 2007) }\end{array}$ & $\begin{array}{l}\text { Burning of iron nails, iron powder and iron wool } \\
\text { 1. Hold the iron nail over the colourless flame of the gas- } \\
\text { burner. When the reaction has started, take the metal off the } \\
\text { flame and hold it over a fireproof pad. } \\
\text { 2. Scatter the iron dust using, for instance, a salt shaker, } \\
\text { through the slantwise located flame of the gas-burner onto a } \\
\text { fireproof pad. } \\
\text { 3. For a short time hold the iron wool over the flame of the } \\
\text { gas-burner. }\end{array}$ \\
\hline \multirow[t]{2}{*}{$\begin{array}{l}\text { Results to be reached by } \\
\text { the students }\end{array}$} & $\begin{array}{l}\text { - Formulate a problem of the research by analysing the content } \\
\text { of the demonstration. } \\
\text { - Put forward a substantiated hypothesis according to the prob- } \\
\text { lem to be studied. } \\
\text { - Formulate the interconnection between the speed of occur- } \\
\text { rence of the chemical reaction and size of contact surface of } \\
\text { the substance. }\end{array}$ \\
\hline & $\begin{array}{l}\text { - Observe the dependent, independent and fixed variables. } \\
\text { - Using the given substances and tools, plan the work proce- } \\
\text { dure of an experiment. }\end{array}$ \\
\hline $\begin{array}{l}\text { Tasks/ question for the } \\
\text { students } \\
\text { (Questions } 1 \text { and } 2 \text { are } \\
\text { asked before the demon- } \\
\text { stration) }\end{array}$ & $\begin{array}{l}\text { 1. What could be studies using this experiment? } \\
\text { 2. Put forward a hypothesis in accordance with the research } \\
\text { questions! } \\
\text { 3. Explain the observations during the experiment and supple- } \\
\text { ment the hypothesis with substantiation. } \\
\text { 4. Draw a more general, extended conclusion according to the } \\
\text { observations of the experiment! }\end{array}$ \\
\hline $\begin{array}{l}\text { Possible answers pro- } \\
\text { vided by students to the } \\
\text { question How does the } \\
\text { degree to which the iron } \\
\text { has been crushed influ- } \\
\text { ence the speed of its burn- } \\
\text { ing? }\end{array}$ & $\begin{array}{l}\text { 1. The more the iron is crushed, the higher is its speed of burn- } \\
\text { ing. } \\
\text { 2. The more the iron is crushed, the higher is its speed of burn- } \\
\text { ing, as the iron and oxygen will blend better thus the contact } \\
\text { surface of these substances is greater. } \\
\text { 3. In chemical reactions with solid substances, the speed is di- } \\
\text { rectly proportional to the size of the contact surface of the } \\
\text { substances. }\end{array}$ \\
\hline $\begin{array}{l}\text { Additional tasks/ ques- } \\
\text { tions after the demon- } \\
\text { stration } \\
\text { (Allows to develop the } \\
\text { skill of observing vari- } \\
\text { ables, plan the work proc- } \\
\text { ess, register data, analyze } \\
\text { them and draw conclu- }\end{array}$ & $\begin{array}{l}\text { 1. Which variable in the demonstrated experiment is independ- } \\
\text { ent and which - dependent? How can one measure the de- } \\
\text { fined independent variable? } \\
\text { 2. Plan an experiment that could confirm the extended conclu- } \\
\text { sion you draw after the demonstration. You are given the fol- } \\
\text { lowing substances and tools: a piece of marble (chalk), } \\
\text { crushed marble (chalk), } 10 \% \text { hydrochloric acid, two } 50 \mathrm{ml} \\
\text { beakers, } 50 \mathrm{ml} \text { measuring cylinder, a spoon, a Petri dish, }\end{array}$ \\
\hline
\end{tabular}




\begin{tabular}{|l|l|}
\hline sions) & $\begin{array}{l}\text { scale, chronometer. } \\
\text { 3. Name the independent, dependent and fixed variables of the } \\
\text { experiment! }\end{array}$ \\
$\begin{array}{l}\text { 4. Carry out the planned experiment, register the obtained data, } \\
\text { analyse them and draw conclusion on the results of the ex- } \\
\text { periment. }\end{array}$ \\
\hline
\end{tabular}

Table 3. Using an experiment to verify the proposed hypothesis.

\begin{tabular}{|c|c|}
\hline Topic of the lesson & Conservation of mass of a substance \\
\hline $\begin{array}{l}\text { The teacher invites students to find } \\
\text { the answer by carrying out a re- } \\
\text { search experiment }\end{array}$ & $\begin{array}{l}\text { Is the mass of reactants equal to the mass of products } \\
\text { in chemical reaction? }\end{array}$ \\
\hline $\begin{array}{l}\text { Results to be reached by the stu- } \\
\text { dents }\end{array}$ & $\begin{array}{l}\text { - Plan the procedure of the experiment to find the } \\
\text { answer to the question on the conservation of mass } \\
\text { of the substance. } \\
\text { - Carry out the experiment. } \\
\text { - Analyse the results obtained through experimenta- } \\
\text { tion. }\end{array}$ \\
\hline $\begin{array}{l}\text { Task } 1 \text { for the students } \\
\text { An experiment "Burning a candle on } \\
\text { the scale" is planned (Rossov, Flint, } \\
2007 \text { ) } \\
\text { Work procedure. The candle is put } \\
\text { on the scale, the mass of the candle } \\
\text { is written down and the candle is lit. } \\
\text { The change in mass is observed. }\end{array}$ & $\begin{array}{l}\text { 1. Draw up the work procedure of the experiment in } \\
\text { accordance with the question on the conservation of } \\
\text { mass of the substance. You are given the following } \\
\text { substances and tools: a candle, matches, scale (ac- } \\
\text { curacy } \pm 0.01 \mathrm{~g}) \text {. } \\
\text { 2. Carry out the experiment. } \\
\text { 3. Analyse the results obtained and give suggestions } \\
\text { on how the experiment can be improved. }\end{array}$ \\
\hline \multicolumn{2}{|c|}{$\begin{array}{l}\text { A teacher together with the students discuss the results of the first experiment and pos- } \\
\text { sibilities to improve upon the experiment in order to establish if the mass of reactants in equal } \\
\text { to the mass of products in the reaction. Students come to a conclusion that, in order to study } \\
\text { the conservation of mass of a substance, it is necessary to create a closed system. }\end{array}$} \\
\hline $\begin{array}{l}\text { Task } 2 \text { for the students } \\
\text { An experiment "Principle of conser- } \\
\text { vation of mass" (Rossov, Flint, } \\
\text { 2007) is planned } \\
\text { Work procedure: } 3 \text { or } 4 \text { matches are } \\
\text { placed inside a test-tube and it is } \\
\text { sealed with a balloon. The test-tube } \\
\text { with the balloon is weighted, and } \\
\text { then heated until the matches catch } \\
\text { fire. When the test-tube has cooled } \\
\text { down to room temperature, the } \\
\text { weighing is repeated. }\end{array}$ & $\begin{array}{l}\text { 1. Plan the procedure for the experiment using a } \\
\text { closed system in order to study the conservation of } \\
\text { mass of a substance. You are given the following } \\
\text { substances and tools necessary for the experiment: } \\
2 \text { test-tubes }(16 \times 160 \mathrm{~mm}), 2 \text { balloons, digital scale } \\
\text { (accuracy } \pm 0.1 \mathrm{~g}) \text {, a test-tube holder, } 3-4 \text { matches. } \\
\text { 2. Carry out the planned experiment. } \\
\text { 3. Analyse the results obtained through experimenta- } \\
\text { tion. } \\
\text { 4. Formulate the principle of conservation of mass of } \\
\text { the substance. }\end{array}$ \\
\hline
\end{tabular}




\section{Conclusions}

The concept "Chemistry for Life" is based on experiments with common everyday substances; its aim is to facilitate active learning process by engaging students in practical activities. As often and reasonable as possible, the so called "laboratory chemicals" are replaced with substances used in everyday life and well-known to the students. At the same time "Chemistry for Life" does not sacrifice the required level of professionalism and follows the best "red thread" trough chemistry.

Such experiments are adaptable to chemistry studies in Latvian schools and applicable in structuring interesting and productive lessons. Students perform experiments with common everyday substances with great interest. By using these simple and easilyunderstandable-by-students experiments, a teacher can structure scientific inquiry based lessons which are interesting for students and where students gradually, step by step, acquire separate skills of scientific inquiry process.

Intensified use of experiments during the lessons increases the opportunity to comprehend chemistry.

\section{References}

Collin, C., Flint, A. (2008). Chemie fürs Leben am Beispiel von Einweggeschirr, Kohlendioxid und Fleckenwasser. Retrieved November 4, 2012, from http://www.chemie1.uni-rostock.de/didaktik/pdf/anfangsunterricht.pdf

Collin, C., Flint, A. (2009). Disposable tableware, carbon dioxide and stain remover - a proposal to introduce chemistry as a school subject according to the concept „Chemistry for life”. International scientific - practical conference „Chemistry Education 2009”. Riga, Latvia, November 6-7, 2009. Conference Proceedings. Riga: University of Latvia, 53-58.

Čižkova, V., Čtrnactova, H. (2011). Science knowledge and skills for life in international studies. International 8th IOSTE Symposium for Central and Eastern Europe. Riga, Latvia, November 30 - December 3, 2011. Scientific Papers University of Latvia, Chemistry, Science Education, 778, 57-64.

Flint, A. (2011). Chemistry for life - a new way to teach and learn chemistry. International 8th IOSTE Symposium for Central and Eastern Europe. Riga, Latvia, November 30 December 3, 2011. Scientific Papers University of Latvia, Chemistry, Science Education, 778, 82-86.

Freienberg, J., Flint, A. (2012). Chemie fürs Leben am Beispiel von Zitronensaft und „Rohrfrei”. Retrieved November 4, 2012, from http://www.chemie1.unirostock.de/didaktik/pdf/Zitronensaft \%20und \%20Rohrfrei \%20I.pdf

Lamanauskas, V., Augienė, D. (2011). Scientific research activity evaluation: Lithuanian upper secondary school students' position. Journal of Baltic Science Education, 10 (3), 195-208.

Rossov, M., Flint A. (2007). Chemie fürs Leben am Beispiel von Kerzen, Oxireinigern und Campinggas. Retrieved November 4, 2012, from http://www.chemie1.unirostock.de/didaktik/pdf/Kerzen, \%20Oxi-Reiniger \%20und \%20Campinggas.pdf

Russell, C. B., Weaver, G. C. (2011). A comparative study of traditional, inquiry-based, and research-based laboratory curricula: impacts on understanding of the nature of science. Chemistry Education Research and Practice, 12, 57-67.

Samete, D., Cedere, D. (2009). Projekta darbu nozīme intereses radīšanā par k̦īmiju un dabaszinībām. [Project works role for interest creation of chemistry and natural sciences.] International scientific - practical conference „Chemistry Education - 2009”. 
Riga, Latvia, November 6-7, 2009. Conference Proceedings. Riga: University of Latvia, 135-140. [In Latvian].

Samete, D., Cedere, D. (2010). Ikdienā lietojamu vielu izmantošana k̦īmijas mācību procesā. [Everyday substance use in the chemistry learning process.] International scientific practical conference „Chemistry Education - 2010”. Riga, Latvia, November 4-5, 2010. Conference Proceedings. Riga: University of Latvia, 88-93. [In Latvian].

Zhou, G. (2010). Conceptual change in science: a process of argumentation. Eurasia Journal of Mathematics, Science \& Technology Education, 6 (2), 101-110.

Гедровицс, Я., Цедере, Д., Еронен, Э., Вереборн, И., Василевская, Е. (2012). Отношение учащихся к школьному естествознанию: сравнительное исследование в Латвии, Беларуси, Финляндии и Швеции. Gamtamokslinis ugdymas / Natural Science Education, 1 (33), 18-28.

Лесиня, Э., Цедере, Д. (2011). Повседневная химия как средство, способствующее повышению учебной мотивации учеников. Konferencijos pranešimu medžiaga „2011 - Tarptautiniai chemijos metai”. Kaunas, Lietuva, 19.04.2011. Kaunas: Kauno technologijos universitetas. 34-38.

Received 10 November 2012; accepted 27 November 2012

\section{$\square$
 Dagnija Cedere}

Associate Professor, Dr. chem., University of Latvia, K. Valdemara Street, 48, Riga, Latvia, LV-1013

E-mail: dagnija.cedere@lu.lv

Website: http://www.lu.lv

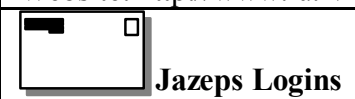

Assistant Professor, Dr. chem., University of Latvia, K. Valdemara Street, 48, Riga, Latvia, LV-1013

E-mail: jlogins@lu.lv

Website: http://www.lu.lv

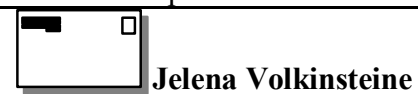

PhD Student, Mg. chem., University of Latvia, K. Valdemara Street, 48, Riga, Latvia, LV-1013

E-mail: gelena-v@inbox.lv

Website: http://www.lu.lv

\section{$\square \quad$ Alfred Flint}

Professor, Dr. chem., University of Rostock, Dr. Lorenz-Weg 1, 18051 Rostock, Germany

E-mail: Alfred.Flint@uni-rostock.de

Website: http://www.didaktik.chemie.uni-rostock.de/ 